Egyptian Poultry Science Journal

http://www.epsaegypt.com

ISSN: 1110-5623 (Print) - 2090-0570 (On line)

\title{
EFFECT OF ENZYMES AND PROBIOTIC MIXTURE SUPPLEMENTATION TO THE DIET ON PERFORMANCE AND CARCASS CRITERIA OF GROWING FEMALES OF THREE RABBIT STRAINS
}

\author{
M. El-Sagheer* and H.H.M. Hassanein ${ }^{1}$ \\ Dep. of Poul. Prod., Fac.of Agric., Assiut Univ., 71526 Assiut, Egypt \\ ${ }^{1}$ Dep. of Anim. and Poul. Prod., Facul. of Agric., South Value Univ., 83523 Qena, Egypt
}

Received: $12 / 02 / 2014$

Accepted: 02/03/2014

\begin{abstract}
A factorial design (3breeds x 3 Supplemented diets) of the present study was determined. A total number of eighty one New Zealand White (NZW), California (CA) and Ve-Line (VL) growing rabbit females strains at 30 days old was similarly body weights averaged (550 $\mathrm{g} \pm 33$ ) and was distributed into 9 groups (G1 to G9), each of three equal replicates. G1 to G3 (Enz0) for NZ, CA and VL strains, respectively were kept untreated and served as controls. G4 to G6 (Enz1) for NZ, CA and VL strains, respectively were supplemented with $1 \mathrm{~g}$ Veta-zyme/kg commercial diet, while the G7 to G9 (Enz2) were supplemented with $2 \mathrm{~g}$ Veta-zyme/kg commercial diet. VETA-ZYME PLUS as a multi enzymes product containing; Each $1 \mathrm{~g}$ contains Amylase $550 \mathrm{U}$, Protease $2000 \mathrm{U}$, Cellulase $400 \mathrm{U}$, Lactobacillus acidophilus 200 millions colony forming units (CFU). The experiment was terminated when rabbits were 72 days old. Body weights (BW), body weight gain (BWG) and feed intake (FI) were recorded. Feed conversion ratio (FCR) was calculated. At the end of the experiment, 6 females for each group were slaughtered to determine carcass criteria. The obtained results could be summarized as follows: No significant differences in BWG, FI and FCR among different strains were observed. Supplementing Enz1 or Enz2 in growing diets exceeded significantly $(\mathrm{P} \leq 0.05)$ exceeded $\mathrm{BW}, \mathrm{BWG}$ and FCR than those of Enz0 during the experimental period (30 to 72 days of age). However, the improvement in FCR and increasing in BW and BWG were higher in Enz1 groups than those of Enz2 ones. Veta-zyme supplemented in diet had no affect on FI. The results reveal that growth performance traits (BW, BWG and FCR) of VL strain with Ezn2 supplemented were increased in all groups as compared with NZW and CA strains. There were no significant differences in carcass criteria under study due to strains or Veta-zyme supplement to diet except liver weight percentage. Enz2 diet had significantly higher liver weight percentage
\end{abstract}

Key Words: Rabbits, strains, enzymes, growth performance, carcass criteria.

Corresponding author: sagheer68@yahoo.com 
than those of Enz1 diet. Conclusively, from these results could be concluded that supplemental Veta-zyme commercial diets at the levels of $1 \mathrm{~g} / \mathrm{kg}$ diet for different female three rabbit strains improved growth performance Moreover; it did not any significant effect on feed intake and carcass criteria.

\section{INTRODUCTION}

The idea of adding enzymes to feeds is old, but its practical implementation dates from the end of the eighties (Choct, 2006). Bedford (2000) indicated that enzyme supplementation in poultry diets improved the nutritional value of cereal grains and their by-products. Improvements in apparent metabolizable energy (Bedford et al., 1998), starch digestibility (Choct and Aannison, 1992) and phytate utilization (Simons et al., 1990) due to added enzyme mixtures had been reported. Being a small non-ruminant herbivore, rabbit feeding is more similar to ruminant feeding than to poultry feeding as rabbit digestive physiology shows some similarity to ruminants, particularly cecal processes (Marounek et al., 2000). Fermentation pattern in rabbit cecum resembles that in the rumen; however, it shows lower fibrolytic microbial activity and relatively higher amylolytic and proteolytic microbial activity (Gidenne, 1997). Feed cost represents $60-70 \%$ of rabbit rearing costs (Makkar et al., 1990) and as consequence, maximizing utilization of nutrients is essential to the profitability and sustainability of rabbit production. Several studies have been attempted for incorporating exogenous enzymes into rabbit diets to improve nutrients availability, however in most trials, rabbits appeared less responsive (Falcão -e-Cunha et al., 2007).

Most of the trials that were performed during the last decade (Tawfeek, 1996; García et al., 2005; Falcão-e-Cunha et al., 2007) could not detect any significant effect of enzymes on rabbit's performance. The only exception was the decrease in mortality rate García et al., (2005) found with proteases and proteases + xylanases (probably reducing protein flow to the caecum). Some positive results were also obtained by other researchers: Eiben et al. (2004), testing cellulase and got improvements in feed conversion ratio and mortality of rabbits weaned at 23 days of age. It is interesting to note that in some trials enzymes supplementation improved fiber digestibility, such was the case in the studies of Gutiérrez et al. (2002a). The latter authors got significant improvements when cellulase and enzyme pool (xylanase, $\beta$-glucanase, $\beta$-gluccosidase, pentosanase, myloglucosidase, acid and neutral protease) was added on NDF (+5\%) and ADF $(+13 \%)$ digestibilities, yet at the same time getting reductions of digestible and metabolizable energies, and nitrogen balance, in comparison with the control diets. The mode of action of enzymes on the different parts of the rabbit gut was addressed by several researchers. Sequeira et al. (2000) could only detect a lowering of gastric $\mathrm{pH}$ but the enzyme complex composed of amylase, xylanase, $\beta$ glucanase and pectinase did not any effect on the digestive parameters measured. Exogenous enzymes frequently fail to significantly affect enzyme activities in the gastric, intestinal and caecal contents (Sequeira et al., 2000), even in the period succeeding early weaning (Falcão-e-Cunha et al., 2007). Although rabbits are better able to digest phytic phosphorus than poultry and swine, they are not equal to ruminants in this regard. In a trial of Gutiérrez et al. (2002b), exogenous phytases improved not only the utilization of phosphorus $(+24 \%)$, but also increased nitrogen digestibility $(+7 \%)$. According to 
these authors, phytases can be useful in rabbit diets.

It is not unlikely that, due to its peculiar digestive physiology, and in particular the fact that caecotrophy casts microbial enzymes along the whole length of the gut (Marounek et al., 1995), rabbits be less responsive than other animals to supplementation with exogenous enzymes. This does not entirely rule out the interest of supplementation, but probably restricts it to particular phases in the life of the rabbits. Hamilton et al. (2003) administered that using adequate amount of live microorganisms have beneficial effects on the health of the animals. Several reviews (Ziermer and Gibson, 1998; Ouwehand et al., 1999; Simon et al., 2003) have suggested a number of possible mechanisms of action of probiotics, among which a reduction of metabolic reactions which produce toxic substances, the stimulation of host enzymes, the production of vitamins or antimicrobial substances, the competition for adhesion to epithelial cells and an increased resistance to colonization, and the stimulation of the immune system of the host. Most microorganisms used in probiotics are strains of Gram-positive bacteria of the genera Bacillus (B. cereus, var. toyoi, B. licheniformis, B. subtilis) Enterococcus (E. faecium), Lactobacillus (L. acidophilus, L. casei, L. farciminis, L. plantarum, L. rhamnosus), Pedicoccus (P. acidilactici) and Streptococcus (S. infantarius). Some yeast and fungi are also used, most frequently some strain of Saccharomyces cerevisae.

Since the European Union banned most of the antibiotic growth promoters in animal nutrition due to cross and multiple resistance (Neu, 1992), much research has been conducted to explore the use of multienzymes as effective substitutes. In some studies the ability of enzymes to be used as alternative growth promoters has already been proven and thus started to play a decisive role in nutrition of poultry. However, there is no data on studies evaluating the performances of different rabbit strains under Veta-zyme supplementation. For this reason, the aim of the present study performed to evaluate the effect Veta-zyme supplementation (Amylase, Protease, Cellulase and Lactobacillus acidophilus) in commercial diet of different female rabbit strains on growth performance traits and carcass criteria.

\section{MATERIALS AND METHODS}

\section{Experimental design:}

A trial was carried out at the Poultry Research Farm, Faculty of Agriculture, South Valley University, Qena, Egypt, from April to May. A factorial design (3strains x 3 Supplemented diets) of the present study was determined. A total number of eighty one growing New Zealand White (NZW), California (CA) and Ve-Line (VL) rabbit female strains at 30 days of age was similarly body weights averaged (550 $\mathrm{g} \pm 33$ ) and was distributed into 9 groups (G1 to G9), each of three equal replicates and each replicate contains 3 rabbits from the same strain. G1 to G3 (Enz0) for NZW, CA and VL strains, respectively were kept untreated and served as controls. G4 to G6 (Enz1) for NZW, CA and VL strains, respectively were supplemented with $1 \mathrm{~g}$ Veta-zyme/kg commercial diet, while the G7 to G9 (Enz2) were supplemented with 2 g Vetazyme/kg commercial diet. VETA-ZYME PLUS as a multi enzymes product containing; Each $1 \mathrm{~g}$ contains Amylase 550 U, Protease 2000 U, Cellulase 400 U, Lactobacillus acidophilus 200 millions colony forming units (CFU), Carrier: Calcium Carbonate up to $1 \mathrm{~g}$.

\section{The environmental climatic conditions:}

Each three rabbits from the same strain were allocated in a cage $(60 \times 50 \times$ $35 \mathrm{~cm}$ for length, width and high, respectively) for 72 days of age in a closed system house using controlled system. Standard commercial management of 
growing rabbit females was used throughout the experiment. Rabbit females were kept at $65 \%$ relative humidity and 22 ${ }^{\circ} \mathrm{C}$ temperature. The photoperiod was 12 hours per day and light intensity ranged from 5 to 10 Luxes. Feed and water were available ad libitum. All growing rabbit females were kept under similar adequate managerial and hygienic conditions until the end of the experiment (72 days old).

\section{The experimental diets:}

All females rabbits received ad libitum a balanced commercial diet (Chemical analysis was crude protein $17.3 \%$, crude fiber $14.9 \%$, ether extract $5.3 \%$, nitrogen free extract $63.7 \%$ and Digestible energy $2603.4 \mathrm{Kcal} / \mathrm{kg}$ diet). The diet is formulated to contain adequate levels of nutrients for growing rabbits as recommended by the National Research Council, (NRC, 1977).

\section{Traits study:}

Rabbits of each replicate were individually weighed every week, feed intake of each replicate was also calculated weekly between the amount of feed supplied and the remaining feed, and then it was every three weeks calculated. Body weight gain (BWG) of each replicate was calculated every three weeks between the final and initial rabbit weight. Feed conversion ratio was calculated every three weeks by dividing total feed consumed in a cage by the total weight gain of its rabbits.

\section{Carcass criteria:}

At the end of the experiment (72 days of age), six rabbits per group (two per replicate) were chosen, weighted and slaughtered to complete bleeding for carcass evaluation. Rabbits were fasted, and then were sacrificed. After slaughtering, the internal organs were removed from the body where the heart, liver, spleen and pancreas were weighed. Head was individually weighed. Dressing (included the liver and heart) and head weights were calculated as percentage of pre-slaughter live body weight, while body organs (heart, liver, spleen and pancreas) were calculated as percentage of carcass weight.

\section{Statistical analysis:}

A factorial design (3 breeds $\mathrm{x} 3$ Supplemented diets) of the present study was determined. Data was subjected to analysis of variance using General Linear Quadratic effects of Veta-zyme supplementation model described in SAS User's Guide (SAS Institute, 2005). The following model was fitted: Yijk $=\mu+\mathrm{Si}+$ Ej+ SEij+ eijK. Where: Yijk = observed value of the concerned treatment. $\mu=$ observed mean for the concerned treatment. $\mathrm{Si}=$ effect due to Strains. Ej= effect due to Enzymes. SEij = interaction effect due to Strains and Enzymes. eijk = the error related to individual observation. Duncan's multiple range test (Duncan, 1955) was used to detect differences among means of different groups,

\section{RESULTS}

\section{Growth performance traits:}

Concerning the strains effect, data presented in Table 1 showed that no significant differences in body weight gain (BWG), feed intake (FI) and feed conversion ratio (FCR) among different rabbit female strains \{New Zealand White (NZW), California (CA) and Ve-Line (VL) \} were observed under study at ages studied except at 51 to 72 days of age for FI . The FI for VL strain significantly $(\mathrm{P} \leq 0.05)$ exceeded those of CA strain, from 51 to 72 days of age, while, there were no significant differences in FI between CA and NZW strains. Concerning the Vetazyme supplemental effect, data presented in Table 1 showed that using 1 or 2 g Vetazyme/kg diet (Enz1 or Enz2, respectively) improved significantly $(\mathrm{P} \leq 0.05)$ body weight (BW), BWG and FCR than those of un-supplemented diet (Enz0) at 30 to 72 days of age. However, the improvement in 
FCR and increasing in BW and BWG were higher in Enz1 diet than those of Enz2 diet. Veta-zyme supplemental in diet had not affect on FI. Concerning the interaction between Veta-zyme supplementation and strains effect, data presented in Table 2 showed that using Enz2 for VL strain (G9) exceeded BW as compared to other groups at 72 days of age. The BWG of G5 and G9 increased than other groups at the period from 30 t0 72 days of age. The G2, 7 and 8 significantly $(\mathrm{P} \leq 0.05)$ decreased FI than other groups during the period from 30 to 72 days of age. In general, supplemental Enz1 or Enz2 diets for G4 to 9 improved FCR than other groups (G1 to 3). The improvement in FCR were higher with G9 and G5 (using Enz2 of VL and Enz1 of CA strains) than other treatments.

\section{Carcass criteria:}

As shown in Table 3, CA strain had significantly higher liver percentage than those of VL and NZW strains. No significant differences were observed in dressing, heart, pancreas, spleen and head percentages among different strains (NZW, CA and VL). The results presented in Table 3 show that, Enz2 diet had significantly higher liver weight percentage than those of Enz1, while there were no significant differences in liver weight percentage between Ezn0 and Ezn2. The supplemental Ezn1 or Ezn2 in commercial diet had not affect on dressing, heart, pancreas, spleen and head weights percentages. No significant differences in carcass criteria (carcass weight and dressing, liver, heart, pancreas, spleen and head weights percentages) among all groups (G1 to G9) were observed (Table 4).

\section{DISCUSSION}

The increase in body weight (BW) and body weight gain (BWG) of female rabbits supplemented with Veta-zyme at 1 or $2 \mathrm{~g} / \mathrm{kg}$ commercial diet are in agreement with the findings of Eiben et al. (2002), Gidenne et al. (2002) and Cachaldora et al.
(2004). The improvement in live BW and BWG of the rabbits fed Veta-zyme may be due to the enhancing effect of enzymes in microflora growth in gut and cecum as well as increase in volatile fatty acids production and organic matter digestibility (Gidenne et al., 2002). Eiben et al. (2002) found that feeding rabbit's diet supplemented with Cellulase enzymes significantly improved weight gain from 23 to 63 and from 63 to 77 days of age, by 17 and 3\%, respectively. Also, Gutiérrez et al. (2002b) showed that addition of enzymes has improved BWG of young rabbits, from 25 to 39 days of age, (by $3.1 \%$ ).

Moreover, Eiben et al. (2004) found that addition of exogenous enzymes in diets of growing rabbits had not affect daily weight gain from day 23 to 77 and $\mathrm{BW}$ at 77 days. This agrees with the finding of Bersenyi et al. (2002), who reported that, amylase supplementation of rabbit diets had not affect daily weight gain. Also, García-Palomares et al. (2006) citied that the addition of proteases $(1 \mathrm{~g} / \mathrm{kg})$ to $\mathrm{New}$ Zealand $\times$ Californian rabbits in the diet containing $16 \%$ crude protein had no effect on growth performances traits (BW, BWG, FC and FCR) in the periods 35 to 49 and 49 to 63 days. García et al. (2005) showed that the supplementation with protease decreased the mortality rate in the first 14 d-period after weaning by a reduction of nitrogen flow at ileum. However, this effect could not be tested in the present study because of the absence of mortality in all groups. The dietary addition of proteases could also help to reduce nitrogen flow but mainly in the post weaning period when animals have a limited enzymatic capacity to hydrolyse the protein (Dojana et al., 1998). Accordingly, the results of GarcíaRuiz et al. (2006) showed that the dietary supplementation with proteases was effective in the reduction of nitrogen ileal flow both for sunflower or soybean based diets.

The present results of feed intake (FI) agree with the fendings of Eiben et al., 
(2004), who reported that the cellulase supplementation (cellulase 11.99 to 52.80 FPU/kg) in diets growing rabbits from 23 to 77 days of age did not affect FI. In contrast, Eiben et al. (2002) and Kocher et al. (2002) found that the average FI of rabbits, during growth period was decreased due to adding enzymes. The obtained results, showed that supplemental Enz1 or Enz2 diets of female rabbits significantly $(\mathrm{P} \leq 0.05)$ improved FCR than those of Enz0 at 30 to 72 days of age and also that using Enz1 or Enz2 of G4 to 7 and G9 improved FCR than other groups (G1 to 3 ). These are in agreement with the findings of Valente et al. (1999). The enhancement in FCR as a result of adding enzymes may be due to the effect of enzymes in improving the digestibility of nutrients (Valente et al., 1999). Eiben et al. (2004) reported that supplementation of diet for early-weaned rabbits with a Cellulase complex reaching 35.20 and 52.80 FPU $/ \mathrm{kg}$ enzyme activity affects positively the FCR between 23 and 77 days of age. This agrees with the finding of Cachaldora et al. (2004), who conducted that enzyme supplementation has beneficial effects on feed efficiency of fattening rabbits.

Contemporary administration of Lactobacillus acidophilus, Streptococcus faecium and $\mathrm{S}$. cerevisiae increases the digestibility of the diet (Gippert et al., 1992; Yamani et al., 1992; El -Hindawy et al.,1993; Kamra et al., 1996), reduces the incidence of enteric diseases (Hollister et al., 1989 \& 1990; Tawfeek and El Hindawy, 1992), especially in conjunction with rations having a high starch content (Nieves-Delgado et al., 1992), increases weight gain (Gippert et al., 1992; Yamani et al., 1992; Ayyat et al., 1996) and improves feed conversion (Hollister et al., 1989 \&1990). Similarly to Luicke et al. (1992). Also Kamra et al. (1996) found no positive change in performance in spite of increased protein digestibility.
Yamani et al. (1992) found that, a pelleted diet supplemented with probiotic improved crude fiber digestibility and weight gain in New Zealand White Rabbits during the growing period, but it not significantly improved FCR. In growing rabbits, Amber et al. (2004), supplementing Lactobacillus acidophilus (Probiotic), found a positive effect on average daily gain $(+9.6 \%)$ and on FCR $(-6.5 \%)$ while no effect was observed on mortality rate. The same author found improvements in the digestibility of nutrients, in particular crude fiber, due to a modification in caecal microflora resulting from an increase in cellulolytic bacteria counts (CFU/mL). Lactobacilli are notably absent from the normal intestinal flora of the rabbit (Cheeke, 1987). The use of Lactobacilli as a Probiotic medication for sick rabbits is common. While, Lactobacillus acidophilus may well be able to survive the rabbit's gastric $\mathrm{pH}$, its usefulness is widely debated. The combined microbial flora of the cecum breaks down ammonia, urea, proteins, and enzymes from the small intestine and cellulose (preferentially in that order). These microbes also have the ability to metabolize xylan and pectin (De Blas and Gidenne, 1998). The products of this metabolism are the protein and enzyme structures of the microbes themselves (which are later digested as cecotrophs), and byproducts of microbial fermentation referred to collectively as volatile fatty acids (acetic, formic, propionic, and butyric acids). These volatile fatty acids (VFAs) are actively absorbed through the cecal and colonic walls and utilized by the rabbit as energy sources, as is the case in ruminants.

There were no significant effects in carcass criteria under study due to strains or Veta-zyme supplemental in diet except liver percentage. CA strain had significantly higher liver percentage than those of VL and CA strains. The groups fed diet supplemented with Enz2 diet had significantly higher liver percentage than those of Enz1. In literature, there is no 
information available on effects of Vetazyme on carcass traits.

\section{CONCLUSIONS}

It may be concluded from the current study that the addition of commercial enzyme mixture (Veta-zyme) at the level of $1 \mathrm{~g} / \mathrm{kg}$ commercial diet for growing female rabbit strains has a beneficial effect on growth performance due to improvement in body weight, body weight gain and feed conversion ratio without any side effects on carcass criteria. 
Table (1): Body weight $(\mathrm{g})$, body weight gain (g/rabbit), feed intake $(\mathrm{g})$ and feed conversion ratio ( $\mathrm{g}$ feed/ $\mathrm{g}$ gain) of growing rabbit female strains received Veta-zyme supplementation.

\begin{tabular}{|c|c|c|c|c|c|c|c|c|c|c|c|c|}
\hline \multirow{2}{*}{$\begin{array}{c}\text { Items } \\
\text { Treatment } \\
\text { groups }\end{array}$} & \multicolumn{3}{|c|}{ Body weight } & \multicolumn{3}{|c|}{ Body weight gain } & \multicolumn{3}{|c|}{ Feed intake } & \multicolumn{3}{|c|}{ Feed conversion ratio } \\
\hline & $\begin{array}{c}\text { Initial } \\
30 \mathrm{~d}\end{array}$ & $51 \mathrm{~d}$ & $72 \mathrm{~d}$ & $30-51 \mathrm{~d}$ & $51-72 d$ & $30-72 \mathrm{~d}$ & $30-51 \mathrm{~d}$ & $51-72 \mathrm{~d}$ & $30-72 \mathrm{~d}$ & $30-51 \mathrm{~d}$ & $51-72 \mathrm{~d}$ & $30-72 \mathrm{~d}$ \\
\hline $\mathrm{NZW}$ & $539 \pm 26$ & $1222 \pm 25$ & $\begin{array}{l}1885^{\mathrm{ab}} \pm 3 \\
7\end{array}$ & $683 \pm 25$ & $663 \pm 35$ & $1346 \pm 37$ & $2153 \pm 55$ & $3043^{\mathrm{ab}} \pm 39$ & $5195 \pm 94$ & $3.16 \pm 0.11$ & $4.71 \pm 0.61$ & $3.87 \pm 0.18$ \\
\hline CA & $539 \pm 46$ & $1246 \pm 36$ & $1842^{\mathrm{b}} \pm 53$ & $707 \pm 37$ & $596 \pm 55$ & $1303 \pm 53$ & $2094 \pm 29$ & $2958^{b} \pm 33$ & $5051 \pm 44$ & $2.97 \pm 0.10$ & $5.10 \pm 0.55$ & $3.91 \pm 0.25$ \\
\hline $\mathrm{VL}$ & $572 \pm 27$ & $1277 \pm 30$ & $1976^{\mathrm{a}} \pm 48$ & $705 \pm 31$ & $699 \pm 37$ & $1404 \pm 49$ & $2134 \pm 21$ & $3169^{a} \pm 46$ & $5305 \pm 29$ & $3.04 \pm 0.17$ & $4.63 \pm 0.45$ & $3.82 \pm 0.29$ \\
\hline $\mathrm{P}$-value & 0.1232 & 0.4673 & 0.0444 & 0.2080 & 0.2492 & 0.2130 & 0.6008 & 0.0504 & 0.1436 & 0.6650 & 0.7688 & 0.9436 \\
\hline $\mathrm{Enz0}$ & $550 \pm 9$ & $1224 \pm 20$ & $1781^{b} \pm 16$ & $674 \pm 20$ & $557^{\mathrm{b}} \pm 21$ & $1231^{\mathrm{b}} \pm 17$ & $2132 \pm 58$ & $3075 \pm 53$ & $5207 \pm 103$ & $3.17 \pm 0.10$ & $5.52 \pm 0.21$ & $4.23^{\mathrm{b}} \pm 0.08$ \\
\hline Enz1 & $557 \pm 5$ & $1273 \pm 26$ & $1997^{\mathrm{a}} \pm 41$ & $716 \pm 27$ & $724^{\mathrm{a}} \pm 27$ & $1440^{\mathrm{a}} \pm 43$ & $2161 \pm 15$ & $3054 \pm 26$ & $5215 \pm 39$ & $3.04 \pm 0.18$ & $4.23 \pm 0.17$ & $3.63^{\mathrm{a}} \pm 0.10$ \\
\hline Enz2 & $543 \pm 5$ & $1248 \pm 42$ & $1925^{\mathrm{a}} \pm 60$ & $705 \pm 42$ & $677^{b} \pm 63$ & $1382^{\mathrm{a}} \pm 58$ & $2089 \pm 20$ & $3043 \pm 110$ & $5131 \pm 115$ & $2.96 \pm 0.07$ & $4.69 \pm 0.66$ & $3.75^{\mathrm{a}} \pm 0.05$ \\
\hline P-value & 0.2289 & 0.5384 & 0.0008 & 0.6229 & 0.0185 & 0.0036 & 0.4943 & 0.8938 & 0.6751 & 0.6034 & 0.2562 & 0.0502 \\
\hline
\end{tabular}

a and $\mathrm{b}$ Means \pm SE within each column for each division (body weight, body weight gain, feed intake and feed conversion ratio) with no common superscripts are significantly different $(\mathrm{P} \leq 0.05)$.

Values in each column are means for 3 replicates of each group ( 9 females per each).

d: Day

NZW, CA and VL were New Zealand White, California and Ve-Line rabbit female strains, respectively.

Enz0, Ezn1 and Ezn2 were supplemented with zero, 1 and $2 \mathrm{~g}$ Veta-zyme/kg commercial diet, respectively. 
Table (2): Effect of interaction of growing rabbit female strains under Veta-zyme supplementation on body weight (BW), body weight gain (BWG), feed intake (FI) and feed conversion ratio (FCR).

\begin{tabular}{|c|c|c|c|c|c|c|c|c|c|c|}
\hline \multirow{2}{*}{$\begin{array}{c}\text { Treatment } \\
\text { groups } \\
\text { Items }\end{array}$} & \multicolumn{3}{|c|}{ Enz0 } & \multicolumn{3}{|c|}{ Enz1 } & \multicolumn{3}{|c|}{ Enz2 } & \multirow{2}{*}{ P-value } \\
\hline & G1 (NZW) & G2 (CA) & G3 (VL) & G4 (NZW) & G5 (CA) & G6 (VL) & G7 (NZW) & G8 (CA) & G9 (VL) & \\
\hline \multicolumn{11}{|l|}{ BW (g): } \\
\hline Initial $30 \mathrm{~d}$ & $535 \pm 8$ & $535 \pm 9$ & $580 \pm 21$ & $558 \pm 13$ & $543 \pm 8$ & $572 \pm 4$ & $523 \pm 7$ & $540 \pm 5$ & $564 \pm 6$ & 0.1238 \\
\hline $51 \mathrm{~d}$ & $1274 \pm 43$ & $1187 \pm 19$ & $1210 \pm 31$ & $1200 \pm 34$ & $1307 \pm 55$ & $1313 \pm 39$ & $1192 \pm 52$ & $1243 \pm 93$ & $1309 \pm 76$ & 0.4798 \\
\hline $72 \mathrm{~d}$ & $1799^{\text {cde }} \pm 40$ & $1757^{\mathrm{de}} \pm 22$ & $1788^{\text {cde }} \pm 17$ & $1954^{\mathrm{abcd}} \pm 69$ & $2043^{\mathrm{ab}} \pm 80$ & $1994^{\mathrm{abc}} \pm 74$ & $1903^{\text {bcde }} \pm 71$ & $1726^{\mathrm{e}} \pm 99$ & $2147^{\mathrm{a}} \pm 65$ & 0.0038 \\
\hline \multicolumn{11}{|c|}{ BWG (g/ rabbit) : } \\
\hline $30-51 \mathrm{~d}$ & $739 \pm 39$ & $652 \pm 20$ & $630 \pm 33$ & $642 \pm 36$ & $764 \pm 57$ & $741 \pm 40$ & $669 \pm 50$ & $703 \pm 96$ & $745 \pm 76$ & 0.5533 \\
\hline $51-72 \mathrm{~d}$ & $525^{\mathrm{cd}} \pm 47$ & $570^{\mathrm{bcd}} \pm 17$ & $578^{\mathrm{bcd}} \pm 41$ & $754^{\mathrm{ab}} \pm 44$ & $736^{\mathrm{abc}} \pm 39$ & $681^{\mathrm{abcd}} \pm 60$ & $711^{\mathrm{abc}} \pm 53$ & $483^{\mathrm{d}} \pm 49$ & $838^{\mathrm{a}} \pm 47$ & 0.0052 \\
\hline $30-72 \mathrm{~d}$ & $1264^{\mathrm{bc}} \pm 43$ & $1222^{\mathrm{bc}} \pm 24$ & $1208^{\mathrm{bc}} \pm 21$ & $1396^{\mathrm{abc}} \pm 73$ & $1500^{\mathrm{a}} \pm 85$ & $1422^{\mathrm{ab}} \pm 75$ & $1380^{\mathrm{abc}} \pm 68$ & $1186^{c} \pm 75$ & $1583^{\mathrm{a}} \pm 68$ & 0.0006 \\
\hline \multicolumn{11}{|l|}{ FI $(g):$} \\
\hline $30-51 \mathrm{~d}$ & $2236^{a} \pm 35$ & $2035^{\mathrm{c}} \pm 18$ & $2123^{\mathrm{abc}} \pm 13$ & $2175^{\mathrm{ab}} \pm 9$ & $2131^{\mathrm{abc}} \pm 15$ & $2176^{\mathrm{ab}} \pm 14$ & $2047^{\mathrm{bc}} \pm 12$ & $2115^{\mathrm{abc}} \pm 16$ & $2103^{\mathrm{abc}} \pm 14$ & 0.0432 \\
\hline $51-72 \mathrm{~d}$ & $3108^{b} \pm 22$ & $2969^{c} \pm 13$ & $3146^{\mathrm{ab}} \pm 25$ & $3048^{\mathrm{bc}} \pm 22$ & $3010^{\mathrm{bc}} 16$ & $3102^{\mathrm{b}} \pm 12$ & $2973^{\mathrm{c}} \pm 11$ & $2895^{c} \pm 12$ & $3259^{a} \pm 40$ & 0.0001 \\
\hline $30-72 \mathrm{~d}$ & $5344^{\mathrm{a}} \pm 73$ & $5004^{\mathrm{b}} \pm 32$ & $5269^{\mathrm{a}} \pm 65$ & $5223^{a} \pm 73$ & $5141^{\mathrm{a}} \pm 37$ & $5278^{\mathrm{a}} \pm 55$ & $5020^{\mathrm{b}} \pm 33$ & $5010^{\mathrm{b}} \pm 32$ & $5362^{\mathrm{a}} \pm 75$ & 0.0001 \\
\hline \multicolumn{11}{|c|}{ FCR ( $\mathrm{g}$ feed/g gain) : } \\
\hline $30-51 \mathrm{~d}$ & $3.03^{\mathrm{bc}} \pm 0.6$ & $3.12^{\mathrm{b}} \pm 0.06$ & $3.37^{\mathrm{a}} \pm 0.06$ & $3.39^{\mathrm{a}} \pm 0.06$ & $2.79^{\mathrm{d}} \pm 0.05$ & $2.94^{\mathrm{bcd}} \pm 0.12$ & $3.06^{\mathrm{b}} \pm 0.04$ & $3.01^{\mathrm{bcd}} \pm 0.06$ & $2.82^{\mathrm{cd}} \pm 0.12$ & 0.0001 \\
\hline $51-72 d$ & $5.92^{\mathrm{a}} \pm 0.29$ & $5.21^{\mathrm{b}} \pm 0.23$ & $5.44^{\mathrm{b}} \pm 0.26$ & $4.04^{\mathrm{c}} \pm 0.12$ & $4.09^{c} \pm 0.23$ & $4.56^{\mathrm{c}} \pm 0.17$ & $4.18^{\mathrm{c}} \pm 0.10$ & $5.99^{\mathrm{a}} \pm 0.23$ & $3.89^{\mathrm{c}} \pm 0.12$ & 0.0001 \\
\hline $30-72 \mathrm{~d}$ & $4.23^{\mathrm{ab}} \pm 0.35$ & $4.09^{\mathrm{ab}} \pm 0.29$ & $4.36^{\mathrm{a}} \pm 0.17$ & $3.74^{\mathrm{abc}} \pm 0.17$ & $3.43^{\mathrm{c}} \pm 0.17$ & $3.71^{\mathrm{bc}} \pm 0.11$ & $3.64^{\mathrm{bc}} \pm 0.08$ & $4.22^{\mathrm{ab}} \pm 0.12$ & $3.39^{c} \pm 0.12$ & 0.0128 \\
\hline
\end{tabular}

a, b, c, d and e Means \pm SE with different superscripts in the same column are significantly different $(\mathrm{P} \leq 0.05)$.

Values in each column are means for 3 replicates of each group ( 9 females per each).

d: Day

NZW, CA and VL were New Zealand White, California and Ve-Line rabbit female strains, respectively.

Enz0 (G1 to 3), Ezn1 (G4 to 6) and Ezn2 (G7 to 9) were supplemented with zero, 1 and $2 \mathrm{~g}$ Veta-zyme /kg commercial diet, respectively. 
Table (3): Carcass criteria of growing rabbit female strains under Veta-zyme supplementation.

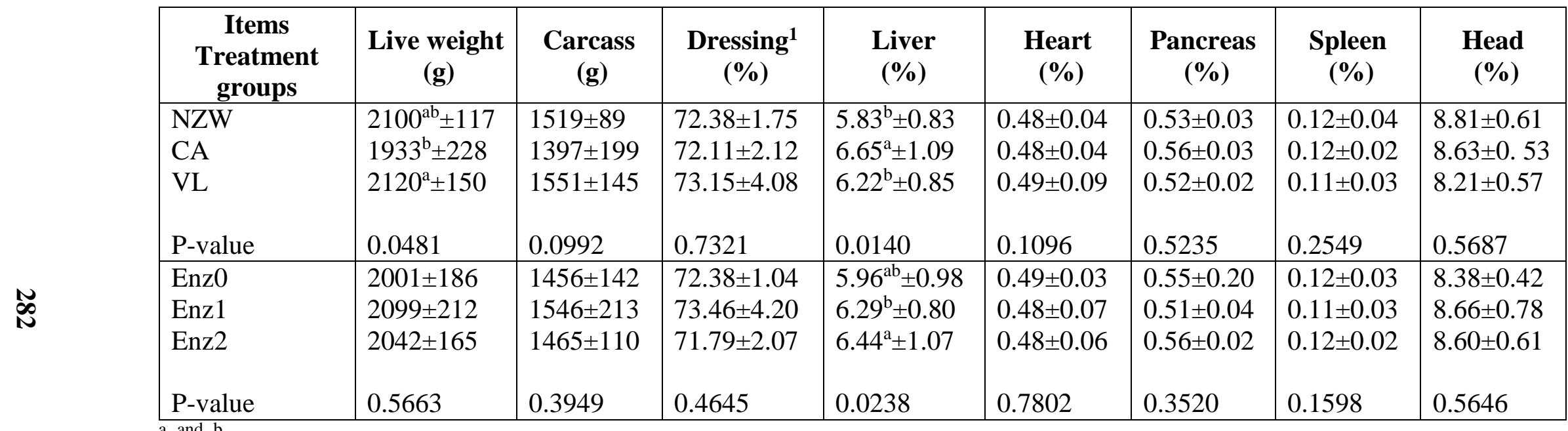

$\mathrm{a}$ and $\mathrm{b}$ Least squares means $\pm \mathrm{SE}$ within each row for each division (carcass criteria) with no common superscripts are significantly different $(\mathrm{P} \leq 0.05)$.

Values in each row are means for 6 rabbits of each group.

NZW, CA and VL were New Zealand White, California and Ve-Line rabbit female strains, respectively.

Enz0, Ezn1 and Ezn2 were supplemented with zero, 1 and $2 \mathrm{~g}$ Veta-zyme/kg commercial diet, respectively.

${ }^{1}$ Dressing weight $(\%)=\{$ Carcass weight + Giblets weight (liver and heart weights) $\} /$ pre-slaughter weight X 100 
Table (4): Effects of interaction of growing rabbit female strains received Veta-zyme supplementation on carcass criteria.

\begin{tabular}{|c|c|c|c|c|c|c|c|c|c|c|}
\hline $\begin{array}{l}\text { Treatment } \\
\text { groups } \\
\text { Items }\end{array}$ & \multicolumn{3}{|c|}{ Enz0 } & \multicolumn{3}{|c|}{ Enz1 } & \multicolumn{3}{|c|}{ Enz2 } & P-value \\
\hline Live weight $(\mathrm{g})$ & $1966 \pm 267$ & $2126 \pm 128$ & $1941 \pm 142$ & $2166 \pm 87$ & $2146 \pm 243$ & $1985 \pm 291$ & $2123 \pm 197$ & $1961 \pm \pm 142$ & $2043 \pm 175$ & 0.7460 \\
\hline Carcass (g) & $1423 \pm 200$ & $1541 \pm 77$ & $1405 \pm 135$ & $1556 \pm 66$ & $1610 \pm 243$ & $1473 \pm 323$ & $1511 \pm 98$ & $1387 \pm 93$ & $1497 \pm 126$ & 0.7939 \\
\hline Liver $(\%)$ & $5.76 \pm 1.06$ & $6.10 \pm 0.87$ & $6.03 \pm 1.16$ & $5.77 \pm 0.65$ & $6.88 \pm 0.48$ & $6.22 \pm 1.15$ & $5.97 \pm 1.26$ & $6.96 \pm 0.52$ & $6.40 \pm 1.40$ & 0.3286 \\
\hline Heart (\%) & $0.49 \pm 0.01$ & $0.48 \pm 0.03$ & $0.50 \pm 0.05$ & $0.48 \pm 0.04$ & $0.48 \pm 0.07$ & $0.49 \pm 0.10$ & $0.47 \pm 0.08$ & $0.48 \pm 0.02$ & $0.48 \pm 0.03$ & 0.1287 \\
\hline Pancreas (\%) & $0.61 \pm 0.02$ & $0.54 \pm 0.02$ & $0.49 \pm 0.02$ & $0.47 \pm 0.02$ & $0.48 \pm 0.05$ & $0.57 \pm .010$ & $0.59 \pm 0.04$ & $0.61 \pm 0.02$ & $0.50 \pm 0.03$ & 0.1660 \\
\hline
\end{tabular}

Values in each row are means for 6 rabbits of each group.

NZW, CA and VL were New Zealand White, California and Ve-Line rabbit female strains, respectively.

Enz0 (G1 to 3), Ezn1 (G4 to 6) and Ezn2 (G7 to 9) were supplemented with zero, 1 and $2 \mathrm{~g}$ Veta-zyme/kg commercial diet, respectively.

${ }^{1}$ Dressing weight $(\%)=\{$ Carcass weight + Giblets weight (liver and heart weights) $\} /$ pre-slaughter weight $\mathrm{X} 100$ 


\section{REFERENCES}

Amber, K.H.; Yakout, H.M.; and Hamed, S. Rawya, (2004). Effect of feeding diets containing yucca extract or probiotic on growth, digestibility, nitrogen balance and caecal microbial activity of growing New Zealand white rabbits. pp 737741 in Proceeding $8^{\text {th }}$ World Rabbit Congress, Puebla, Mexico. http://world-rabbit-science.com /WRSA-Proceedings/Congress2004-Puebla/Papers/Feeding-\%26Nutrition/N-Amber.pdf.

Ayyat, M.S.; Marai, I.F.M.; and ElAasar, T.A., (1996). New Zealand white rabbit does and their growing off springs as affected by diets containing different protein level with or without Lacto-Sacc supplementation. World Rabbit Science 4:225-230. http://riunet.upv .es/bitstream/handle/10251/10452/2 99-527-1-SM.pdf?sequence $=1 \&$ is Allowed $=\mathrm{y}$.

Bedford, M.R., (2000). Exogenous enzymes in monogastric nutrition their current value and future benefits. Animal Feed Science Technology 86:1-13. http://dx.doi .org/10.1016/S0377-840100)001553.

Bedford, M.R.; Scott, T.A.; Silverside, F.G.; Classen, H.L.; Swift, M.L.; and Pack, M., (1998). The effect of wheat cultivar, growing environment and enzyme supplementation on digestibility of amino acids by broilers. Canada Journal Animal Science 78:335342. http://dx.doi.org/10.4141/A98012.

Bersenyi, A.; Faigl, Z.S.; Reczey, K.; and Faigl, V., (2002). Amylase supplementation of rabbit diets. $14^{\text {th }}$ Hungarian Conference on Rabbit Production, Kaposvár Hungary, World Rabbit Science 10:176
(Abstract).

http://ojs.upv.es/index.php/wrs/artic le/viewFile/490/477.

Cachaldora, P.; Nicodemus, N.; Garcia, J.; Carabaño, R.; and De Blas, J.C., (2004). Efficacy of amylofeed ${ }^{\circledR}$ in growing rabbit diets. World Rabbit Science 12:23 - 31 . http://ojs.upv.es/index.php/wrs/artic le/viewFile/583/570.

Cheeke, P.R., (1987). Digestive physiology. In: Rabbit feeding and nutrition. Orlando: Academic Press; p. 15-33. http://dx.doi.org/10.1016 /B978-0-08-057078-5.50008-X.

Choct, M., (2006). Enzymes for the feed industry: past, present and future. World's Poultry Science Journal 62:5-15. http://dx.doi.org /10.1079/WPS200480.

Choct, M., and Annison, G., (1992). The inhibition of nutrient digestion by wheat pentosans. British Journal Nutrition 67:123-132.http://dx.doi. org/10.1079/BJN19920014- PMid: 1547198.

De Blas, E., and Gidenne, T., (1998). Digestion of sugars and starch. In: de Blas E, Wiseman J, editors. 1998. The nutrition of the rabbit. allingford: CABI Publishing; p. 1938. http://bookshop.cabi.org /Uploads/Books/PDF/97818459366 93/9781845936693.pdf.

Dojana, N.; Costache, M.; and Dinischiotu, A., (1998). The activity of some digestive enzymes in domestic rabbits before and after weaning. Animal Science 66:501507. http://dx.doi.org/10.1017 /S135772980000967X.

Duncan, D.B., (1955). Multiple range and multiple tests. Biometrics 11:1-42.

Eiben, C.S., M. Mézes, N. Zijártó, K. Kustos, K. Gódor-Surmann, and M. Erdélyi, (2004). Dosedependent effect of cellulase supplementation on performance of early-weaned rabbit. In Proceeding: 
$8^{\text {th }}$ World Rabbit Congress, Puebla, México, 799-804. http://worldrabbit-science.com/WRSA-

Proceedings/Congress-2004-Puebla /Papers/Feeding-\&-Nutrition/NEiben-1.pdf.

Eiben, C.S.; Szijártó, N.; Mézes, M.; Kustos, K.; Gódor-surmann, K.; and Réczey, K., (2002). Effect of dietary cellulase enzyme supplementation on the performance of early weaned rabbits. $14^{\text {th }}$ Hungarian Conference on Rabbit Production, Kaposvár (Hungary), World Rabbit Science 10:176 (Abstract). http://ojs.upv.es/index .php/wrs/article/viewFile/490/477.

Falcão -e-Cunha, L.; Castro-Solla, L.; Maertens, L.; Marounek, M.; Pinheiro, V.; Freire, J.; and Mour, J.L., (2007). Alternatives to antibiotic growth promoters in rabbit feeding: a review. World Rabbit Science 15:127-140. http://ojs.upv.es/index.php/wrs/artic le/download/597/584.

García, A.I.; García, J.; Corrent, E.; Chamorro, S.; García-Rebollar, P.; De Blas, J.C.; and Carabaño, R., (2005). Effet de l'âge du lapin, de la source de protéine et de l'utilisation d'enzymes sur les digestibilités apparentes de la matière sèche et de la protein brute sur un aliment lapin. In Proc.: 11èmes Journées de la Recherche Cunicole, Paris, France, 197-200. PMCid:PMC1201644.

García-Palomares, J.; Carabaño, R.; García-Rebollar, P. ; De Blas, J.C.; Corujo, A.; and GarcíaRuiz, A.I.; (2006). Effects of a dietary protein reduction and enzyme supplementation on growth performance in the fattening period. World Rabbit Science 14: 231 236. http://ojs.upv.es/index.php/wrs /article/download/564/551.
García-Ruiz A.I.; García-Palomares, J.; García-Rebollar, P.; Chamorro, S.; Caraba-o, R.; and De Blas, J.C., (2006). Effect of proteinsource and enzyme supplementation on ileal protein digestibility and fattening performance in rabbits. Spanish Journal Agriculture Research 4:297-303. http://dx.doi .org/10.5424/sjar/2006044-207.

Gidenne, T., (1997). Caeco-colic digestion in the growing rabbit: impact of nutritional factors and related disturbances. Livestock Production Science 51:73-88. http://dx.doi.org /10.1016/S0301-622697)00111-5.

Gidenne, T.; Jehl, N.; Segura, M.; and Michalet-Doreau, B., (2002). Microbial activity in the caecum of the rabbit around weaning: impact of a dietary fiber deficiency and of intake level. Animal Feed Science and Technology 99:107-118. http://dx.doi.org/10.1016/S0377840102)00138-4.

Gippert, T.; Virag, G.; and Nagy, I., (1992). Lacto-Sacc in rabbit nutrition. Journal of Applied Rabbit Research 15:1101-1104.

Gutiérrez, I.; Espinosa, A.; García, J.; Carabaño, R.; and De Blas, J.C., (2002a). Effect of levels of starch, fiber and lactose on digestion and growth performance of early weaned rabbits. Journal Animal Science 80:1029-1037. PMid: 12002309.

Gutiérrez, I.; Espinosa, A.; García, J.; Carabaño, R.; and De Blas, J.C. (2002b). Effects of exogenous phytase on phosphorous and nitrogen digestibility in growingfinishing rabbits. In Proc.: $7^{\text {th }}$ World Rabbit Congress, Valencia, Spain, 277-281. PMid:12136071.

Hamilton-Miller, J.M.T.; Gibson, G.R.; and Bruck, W., (2003). Some insights into the derivation and early uses of the word probiotic. British 
Journal Nutrition, 90:845. http://dx.doi.org/10.1079/BJN20039

54 - PMid:14552330.

Hollister, A.G.; Cheeke, P.R.; Robinson, K.L.; and Patton, N.M., (1989). Effect of water-administered probiotics and acidifiers on growth, feed conversion and enteritis mortality of weanling rabbits. Journal of Applied Rabbit Research 12:143-147.

Hollister, A.G.; Cheeke, P.R.; Robinson, K.L.; and Patton, N.M., (1990). Effect of dietary probiotics and acidifiers on performance of weanling rabbiJts. Journal of Applied Rabbit Research 13:6-9.

Kamra, D.N.; Chaudhary, L.C.; Singh, R.; and Pathak, N.N., (1996). Influence of feeding probiotics on growth performance and nutrient digestibiliitny rabbits. World Rabbit Science 4:85-88. http://ojs.cc.upv.es /index.php/wrs/article/viewFile/276/ 263.

Kocher, A.; Choct, M.; Proter, M.D.; and Borzt, J., (2002). Effect of feed enzymes on nutritive value of soybean meal fed to broilers. British Poultry Science 43:54-63. http://dx.doi.org/10.1080/00071660 120109890 - PMid:12003339.

Luicke, B.R.; El-Sayaad, G.A.E.; and Cheeke, P.R., (1992). Effects of fructooligosaccharidesa and yeast culture on growth performancoe $\mathrm{f}$ rabbits. Journal of Applied Rabbit Research 15:1121-1 128.

Makkar, H.P.; Singh, B.; and Krishna, L., (1990). Effect of feeding urea on some hydrolytic and ammonia assimilation enzymes in rabbit cecum. Journal of Applied Rabbit Research 13 35-38. http://www.cabdirect.org/abstracts/1 9911429060.html; jsessionid $=645 \mathrm{~A} 8$ 1D0378C695D4FC2FAEBE1307B $3 \mathrm{~B}$.
Marounek, M.; Brezina, P.; and Baran, M., (2000). Fermentation of carbohydrates and yield of microbial protein in mixed cultures of rabbit caecal microorganisms. Archives of Animal Nutrition 53:241-252. PMID:11006829 .

Marounek, M.; Vovk, S.; and Skrivanová, V., (1995). Distribution of activity of hydrolytic enzymes in the digestive tract of rabbits. British Journal Nutrition 73:463-469. http://dx.doi.org /10.1079/BJN19950048 - PMid: 7539289 .

Neu, H.C., (1992). The crisis in antibiotic resistance. Science 257:1064-1073. http://dx.doi.org/10.1126/science.25 7.5073.1064 - PMid:1509257.

Nieves-Delgado, D.; Pro-Martínez, A.; Herrera-Haro, J.; and Velázquez, J., (1992). Effect of probiotics on the use of mash diets with high and low alfalfa meal content in rabbits. Journal of Applied Rabbit Research 15:1160-1 162.

NRC, (1977). Nutrient requirements of rabbits. National Academic of Science, Washington DC, USA.

Ouwehand A.C.; Kirjavainen, P.V.; Shortt, C.; and Salminen, S., (1999). Probiotics: mechanisms and established effects. International Dairy Journal 9:43-53. http://dx.doi.org/10.1016/S0958694699)00043-6.

SAS Institute, (2005). User's Guide: Statistics. Version 9.1. SAS Institute, Inc., Cary, North Carolina, USA. http://support.sas.com/rnd /itech/updates/91/dev_guide.pdf .

Sequeira, J.; Nicodemus, N.; Carabaño, R.; and Villamide, M.J., (2000). Effect of type of wheat and addition of enzymes on some digestive parameters at different sampling time. In Proceeding: $7^{\text {th }}$ World Rabbit Congress. Valencia, Spain, 437-444. http://world-rabbit-science 
.com/WRSA-Proceedings/Congress -2000-Valencia/Papers/Nutrition\& \%20Digestion/N53-Sequeira.pdf.

Simon, O.; Vilfried, V.; and Scharek, L., (2003). Micro-organisms as feed additives - probiotics. In Proceeding: $9^{\text {th }}$ International Symp. on Digestive Physiology in Pigs, Banff, AB, Canada, 295-318. PMid:14558851 .

Simons, P.C.M.; Versteegh, H.A.G.; Jongbloed, A.W.; Kemme, P.A.; Slump, P.; Bos, K.D.; Wolters, M.G.E.; Beudeker, R.F.; and Verschoor, G.J., (1990). Improvement of phosphorus availability by microbial phytase in broilers and pigs. British Journal Nutrition 64:525-540. http://dx.doi.org/10.1079/BJN19900 052 - PMid:2171634.

Tawfeek, M.I., (1996). Effect of feeding system and supplemented diet with Kemzyme on growth, blood constituents, carcass traits and reproductive performance in rabbits. Egyptian Journal of Rabbit Science 6 (1) :21-37.

Tawfeek, M.I., and El -Hindawy, M.M., (1992). Reproduction and growth of NZW and Cal rabbits as affected by supplementations with Lacto Sacc during summer. Egyptian Journal of Rabbit Science 1 (2):124-135.
Tawfeek, M.I., and Marai, I.F.M., (1997). Use of probiotic in small animals production. International Conference on Animal Production and Health, 2-4 September, Cairo, 71-90.

Valente, S.S.; Ferreira, W.M.; Santiago, G.S.; Dias, J.C.C.A.; and Cavalcante, S.G., (1999). Effect of enzymatic supplementation on growth performance of rabbits. World Rabbits Science 7:41. http://pan-am.uniserve.com/pg 000083.htm\#vol7.

Yamani, K.A.; Ibrahim, H.; Rashwan, A.A.; and El-Gendy, K.M., (1992). Effects of a pelleted diet supplemented with probiotic LactoSacc) and water supplemented with a combination of Probiotic and acidifier Acid-Pak 4Way) on digestibility, growth carcass and physiological aspects of weanling New Zealand White rabbits. Journal of Applied Rabbit Research 15:1087-1100.

Ziermer, C.J., and Gibson, G., (1998). An overview of probiotics, prebiotics and symbiotics in the functional food concept: perspectives and futures strategies. Dairy Journal 8:473-479. http://dx.doi.org/10.1016/S0958694698)00071-5. 


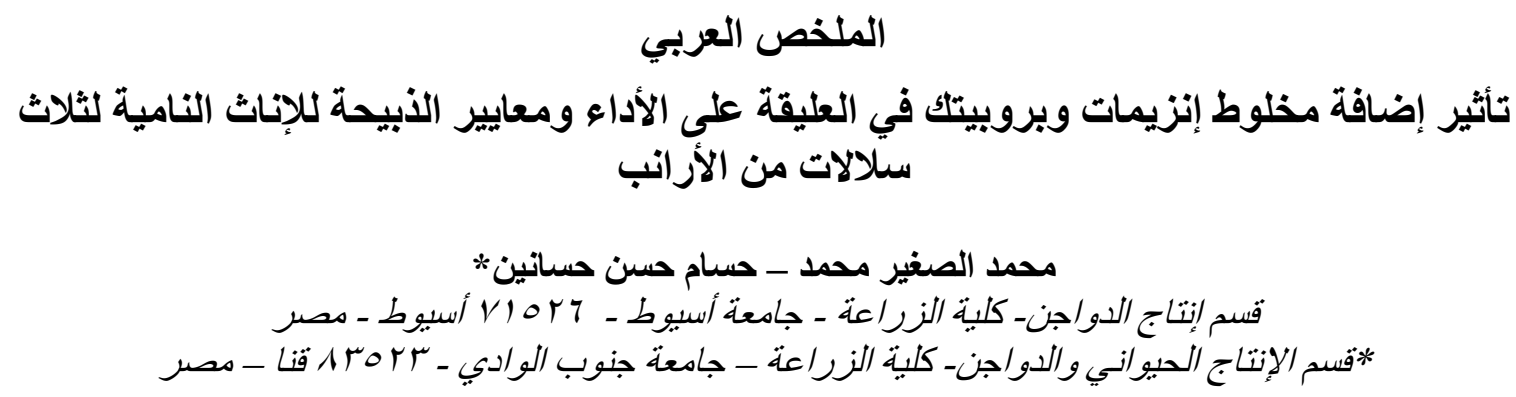

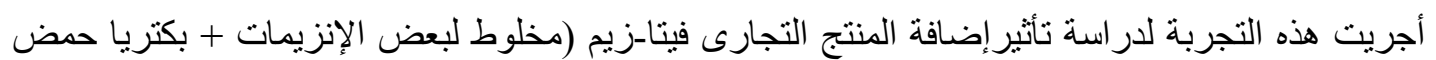

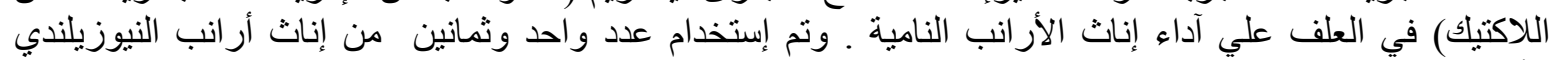

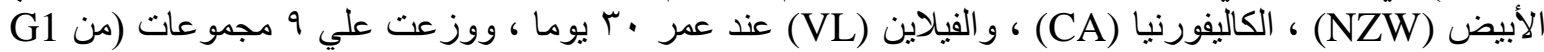

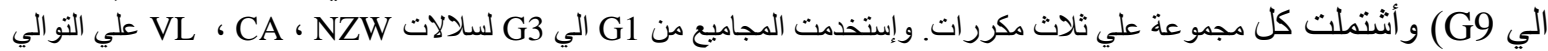

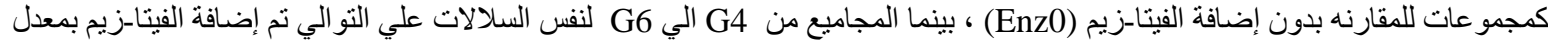

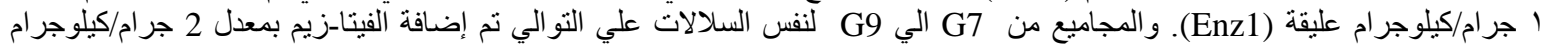

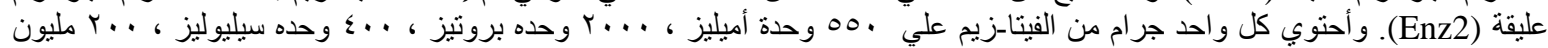

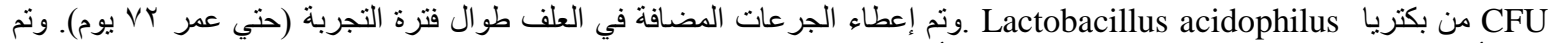

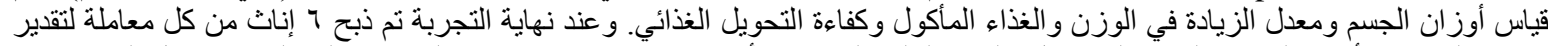

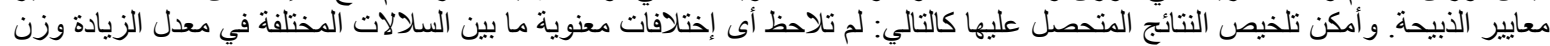

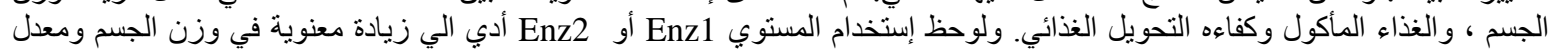

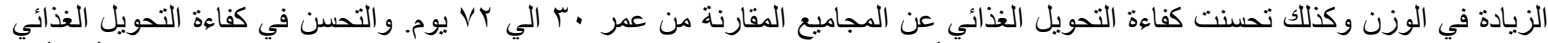

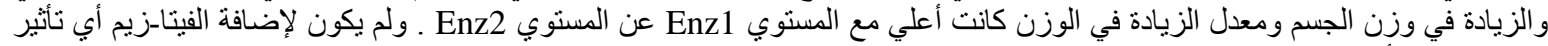

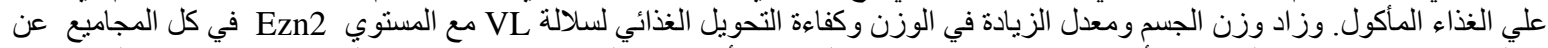

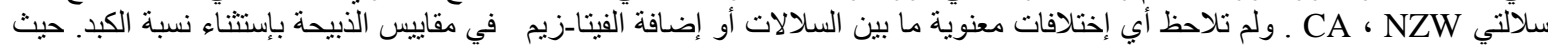

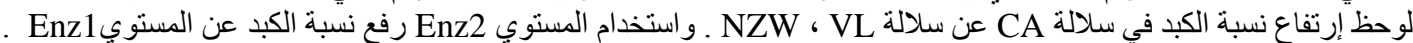

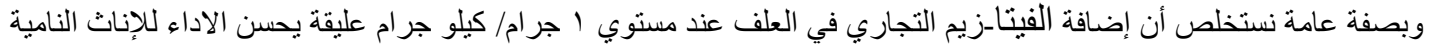

لكل السلالات الثلاثة المختلفة للأر انب ، وبدون أي تأثير علي الغذاء المأكول ومقاييس الذبيحة. 